\title{
Dynamics and driving factors of agricultural landscape in the semiarid hilly area of the Loess Plateau, China
}

\author{
Qiu-Ju Zhang ${ }^{\text {a }}$, Bo-Jie Fu ${ }^{\text {a,* }}$, Li-Ding Chen ${ }^{\text {a }}$, Wen-Wu Zhao ${ }^{\text {a }}$, \\ Qin-Ke Yang ${ }^{\mathrm{b}}$, Guo-Bin Liu ${ }^{\mathrm{b}}$, Hubert Gulinck ${ }^{\mathrm{c}}$ \\ ${ }^{a}$ Key Laboratory of Systems Ecology, Research Center for Eco-Environmental Sciences, Chinese Academy of Sciences, \\ P.O. Box 2871, Beijing 100085, PR China \\ ${ }^{\mathrm{b}}$ Institute of Soil and Water Conservation, Chinese Academy and Sciences and Ministry of Water Resources, \\ P.O. Box 26, Yangling, Shannxi 712100, PR China \\ ${ }^{\mathrm{c}}$ Department of Land Management, Katholieke Universiteit Leuven, Vital Decosterstraat 102, 3000 Leuven, Belgium
}

Received 23 April 2003; received in revised form 28 October 2003; accepted 13 November 2003

\begin{abstract}
Poor vegetation cover as a result of irrational land use is generally considered to be the major factor of soil erosion in the Loess Plateau in China. However, there is lack of knowledge concerning the dynamics of land use and the complex role of socio-economic policy factors in inducing changes in land use, especially at detailed scale levels such as in individual small catchments. This study analyzes the process of human-induced landscape change in a small catchment in the northern part of the Chinese Loess Plateau from 1958 to 1999. During this period, a significant reduction of the area of farmland on steeper slopes and an increase in woodland took place. Household questionnaires among the local farmers, a review of the historic events and literature allowed the assessment of socio-economic and policy forces that caused these changes. The research showed that the changes of agricultural landscape pattern are mainly the result of the dissolution of People's Communes in 1979 (established in 1956), the introduction of a Household Responsibility System (in 1978), the implementation of the Family Planning policy (in 1978), and the adoption of a market-directed economic system (in 1992), as well as the execution of an integrated soil erosion control project (begun in 1981). The changes of the agricultural landscape show the benefits in both ecological and economic respects.
\end{abstract}

(c) 2003 Elsevier B.V. All rights reserved.

Keywords: Agricultural landscape change; Driving force; Policy reform; Integrated soil erosion control project; The Loess Plateau, China

\section{Introduction}

Agricultural landscapes are mosaics of natural and human-managed patches that vary in size, shape and arrangement (Forman and Gordron, 1986). The spatial pattern in the landscape may influence a variety

\footnotetext{
* Corresponding author. Tel.: +86-10-685-97542; fax: +86-10-629-43840.

E-mail address: bfu@mail.rcees.ac.cn (B.-J. Fu).
}

of ecological processes, such as water runoff and erosion (Peterjohn and Correll, 1984; Burel et al., 1993; Fu et al., 1994; Fu and Chen, 2000). Local land-use and land-cover change can play a pivotal role in environmental and ecological changes and furthermore contribute to global change (Meyer and Turner II, 1991; Imberson, 1999; Wilson et al., 2003).

The understanding of the natural and social factors that influence land-use and land-cover change is far from complete (Bürgi and Turner, 2002). In some 
regions, land-use changes appear to be closely related to the physical attributes of landscape (Seilbernagel et al., 1997; Paquette and Domon, 1997); in other regions, mainly socio-economic processes influence the land-use changes (Krausmann et al., 2003; Poudevigne et al., 1997). Some studies show that the changes of land use are constrained by both physical and socio-economic factors (Rao and Pant, 2001; Kammerbauer and Ardon, 1999; Reenberg, 2001). The study of land-use and land-cover changes and their driving force is a major objective of landscape ecology, since it yields insight in pattern-process relations at landscape level.

The Loess Plateau lies in the middle reaches of the Yellow River. It is seriously affected by soil erosion. The rate of soil erosion reached $5000-10,000 \mathrm{Mg} \mathrm{ha}^{-1}$ per year, and in some areas, it is even reached to 20,000 $\mathrm{Mg} \mathrm{ha}^{-1}$ per year (COSTLOP-CAS, 1991; Jiang, 1997; Chen et al., 2001). The driving factors for such quantities of soil erosion are multifold. Most important cause is irrational land use and poor vegetation coverage on the Loess Plateau (Fu, 1989; Fu and Gulinck, 1994; Jiang, 1997). Agriculture is the principal economic activity in the Loess Plateau region. Because of the increase in population and the concomitant requirement of grain after the establishment of the People's Republic of China, the reclamation of farmland increased, which resulted in the acceleration of deforestation and cultivation of grassland. In order to control soil erosion, it is critical to adjust the agricultural landscape through the redesign of the land-use pattern and composition. The Chinese government has increasingly paid attention to soil erosion control and agricultural development in the Loess Plateau. As a result, the agricultural landscape changed significantly and the local environment has greatly improved consequently since the execution of the integrated soil erosion control project in 1981.

The Zhifanggou small catchment of the northern Loess Plateau China was chosen as a case study area to analyze the process of man-induced agricultural landscape change and the complex relationship between economic, social and policy factors that induced the changes in land-use patterns from 1958 to 1999 . The objectives of this study were to: (1) identify the agricultural landscape change process of small catchments in the northern Loess Plateau China within the past 41 years; and (2) analyze the main socio-economic driving forces of the agricultural landscape changes after the establishment of People's Republic China.

\section{Materials and methods}

\subsection{The study area}

The case study area, Zhifanggou catchment, is located in the An'sai county of Shannxi province in the northern part of the Loess Plateau $\left(36^{\circ} 51^{\prime} \mathrm{N}\right.$, $109^{\circ} 19^{\prime} \mathrm{E}$ ), covering about $8.3 \mathrm{~km}^{2}$. There are three villages in this catchment, called Shiyaoxian, Washuta and Zhifanggou, with 552 habitants in 2002. The catchment comprises a typical loess hill and gully landform with gully density of $8.1 \mathrm{~km} \mathrm{~km}^{-2}$. This region has a typical semiarid continental climate with an average temperature of $8.8^{\circ} \mathrm{C}$ and an average annual precipitation of $549 \mathrm{~mm}$ with high variability (about $61 \%$ of the rain falls between July and September). The soils in this part of the Loess Plateau, orientated in a southwest-northeast belt, are classified as Calcic Cambisols according to the soil map of the world (FAO-UNESCO, 1974). The most common soil in this catchment develops on loess soil and has a texture dominated by fine silt. The soil is fertile but weakly resistant to erosion (Fu, 1989; Fu and Gulinck, 1994).

\subsection{Land-use database}

In this study, multi-temporal sets of land-use maps were collected for studying the changes in the agricultural landscape-over the time series 1958, 1978, 1987, 1990, 1995 and 1999. The maps were prepared by the Institute of Soil and Water Conservation, Chinese Academy of Sciences \& Ministry of Water Resource through the interpretation of aerial photographs scale 1:10,000. The agricultural landscape in the study area was classified into farmland, including irrigated farmland, terrace farmland, slope farmland, check-dam farmland (check-dam farmland: flat land behind a dam, which is formed when a small reservoir full of silt deposit was used for crop production), woodland (orchard land, dense woodland, sparse woodland, shrub land), grassland and 
other (residential area, water body and unused land). The six temporal land-use maps constitute the spatial database.

\subsection{Methods}

In order to describe the overall agricultural landscape structure changes over time and measure the rate of change, a spatial analysis was carried out using a geographical information system by an overlaying operation (GIS, ArcInfo Version 3.4 and ArcView Version 3.1, ESRI, Redlands, USA). Through intersecting the six land-use layers successively, five land-use transformation layers (1958-1978, 1978-1987, 1987-1990, 1990-1995 and 1995-1999) were extracted. Querying their attribute table, the plots which land-use type had changed were located and the transformation matrices produced to help understand the source of the change.

To capture the socio-economic driving factors of agricultural landscape change, many aspects need to be considered. Factors that were hypothesized to be determinants of the agricultural landscape change were selected based on a review of literature dealing with this region. Because detailed information for all factors could not be found, certain variables were included that could be regarded as proxies for the explanatory factors. "The historical event", for example, could be considered as an indicator of "the impact of policy reform on agricultural landscape". "Population" determines "the burden of agriculture", whereas "grain production" could be representative of "the ability of agriculture".

For collecting information on land-use change, reform of land policy, economic development and the environmental change in the study area, household questionnaires were carried out in 2002 among the local farmers of the study area. The major purpose was to have a general understanding of: (1) the change of main type of land use; (2) the history and exact time of land-use policy change; (3) the population dynamic and the family planning policy implementation; (4) the community activity within the catchment, such as building terraces and the construction of check-dams; (5) the implementation of the soil and water conservation project; (6) the household income structure; and (7) the farmers' response to the soil and water conservation measures.

\section{Results}

\subsection{Change of agricultural landscape}

\subsubsection{Change frequency of agricultural landscape}

The change frequency of agricultural landscape in the five periods was defined by the number of the plots changed times in land-use type during the 41 years period and was presented as a change frequency map (Fig. 1). For example, 536 plots, representing 64.4\% of the total area, have changed at least once. Only 243 plots $(35.6 \%$ of the total area) remained unchanged according to the time sampling (Table 1). The plots that changed twice and three times in the five intervals, were 16.6 and $4.8 \%$ of the total area, respectively. Only a few plots changed four or five times. The total

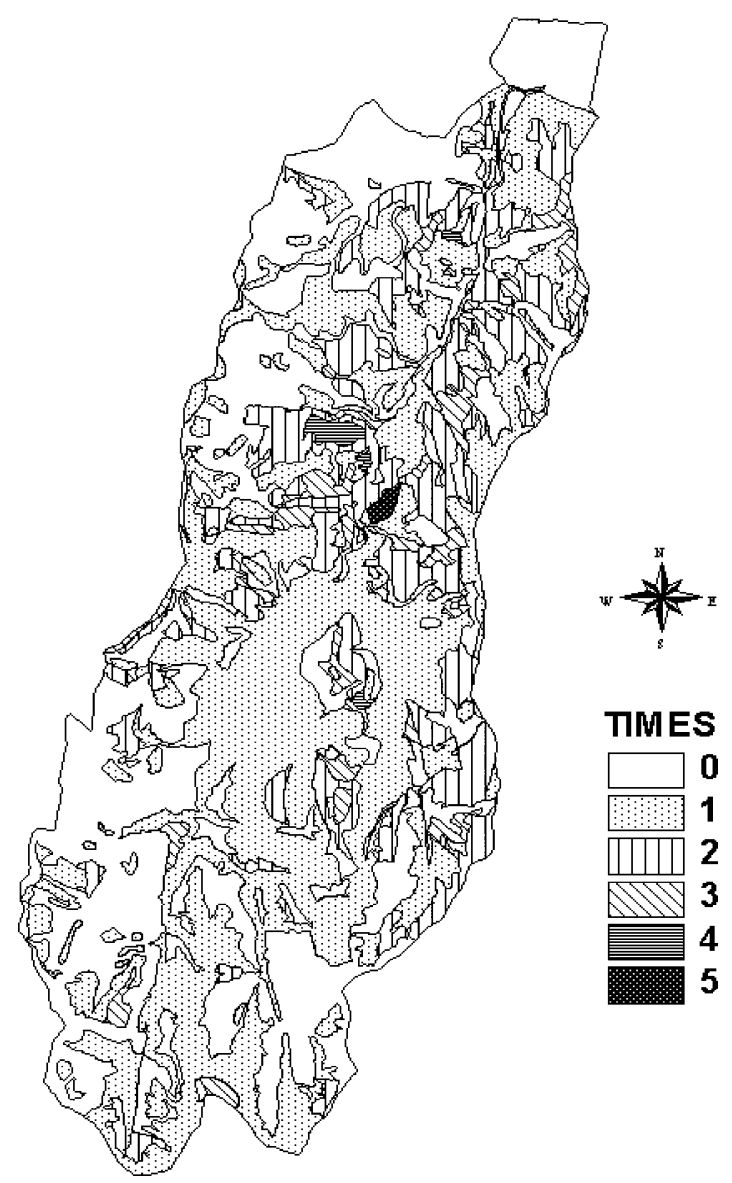

Fig. 1. Agricultural landscape change frequency in Zhifanggou catchment during study periods. 
Table 1

Statistics of agricultural landscape change in Zhifanggou catchment during the five periods

\begin{tabular}{lll}
\hline $\begin{array}{l}\text { Frequency of } \\
\text { land-use change }^{\mathrm{a}}\end{array}$ & $\begin{array}{l}\text { Number } \\
\text { of plots }\end{array}$ & $\begin{array}{l}\text { Area percentage } \\
(\%)\end{array}$ \\
\hline 0 & 243 & 35.6 \\
1 & 313 & 42.3 \\
2 & 164 & 16.6 \\
3 & 54 & 4.8 \\
4 & 4 & 0.5 \\
5 & 1 & 0.2 \\
\hline
\end{tabular}

${ }^{\text {a }}$ Frequency of land-use change of the plots during the five intervals: 0 , unchanged; 1 , changed only once; 2 , changed twice; 3 , changed thrice; 4 , changed four times; 5 , kept changing in five intervals.

area of modified plots occupied $64.4 \%$ of the study area (Table 1).

\subsubsection{Change process of agricultural landscape}

Fig. 2 displays the overall land-cover changes from 1958 to 1999 . The most important change of the agricultural landscape in Zhifanggou catchment was a decline in farmland and an increase in woodland. In 1958 , about $58.2 \%$ of the study area was covered by farmland and only $0.2 \%$ by woodland. In 1978 , farmland was reduced to $50.5 \%$ whilst woodland increased to $4.4 \%$ of the study area. In 1987 , farmland had decreased to $38.2 \%$ and woodland increased to $23.0 \%$. After 1987, farmland continued declining while woodland kept increasing. By the end of 1999, the proportion of farmland, woodland and grassland was 19.3, 38.6 , and $41.2 \%$, respectively.

Although the total area of farmland decreased, the overall quality of the farmland was improved

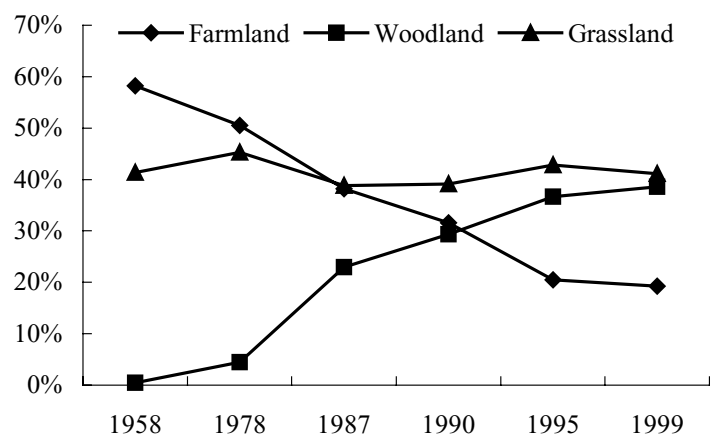

Fig. 2. Change of agricultural landscape structure in Zhifanggou catchment from 1958 to 1999 based on three main land-use groups. through terracing and the construction of check-dam (Fig. 3a-e). The proportion of woodland increased in different stages and types. The 'sparse woodland' increased in 1958-1978 and 1978-1987, as well as 1990-1995, whereas 'dense woodland' and 'shrub land' generally increased during 1978-1987 and 1987-1990 (Fig. 3a-c). In addition, the 'orchard land' increased in each period. The total area of grassland showed a fluctuating profile from 1958 to 1999 (Fig. 3a-e).

The magnitude and the acquisition of each kind of agricultural landscape types changed during five intervals (1958-1978, 1978-1987, 1987-1990, 1990-1995, 1995-1999). From 1958 to 1978, the most remarkable change was the increase of terrace farmland and check-dam farmland reclaimed from slope farmland and unused land. From 1978 to 1987, dense woodland appeared at the cost of slope farmland. Eight percent of slope farmland in 1987 was converted to terrace farmland, which made up $44.4 \%$ of terrace farmland in 1990, while $3.6 \%$ of grassland in 1987 was converted to sparse woodland in 1990. Slope farmland in 1995 decreased to about $85.4 \%$ of that found in 1990 and further decreased to $64.5 \%$ from 1995 to 1999. It was mainly converted to terrace farmland. Another important change was the unused land, which had been completely used and mainly converted into grassland and dense woodland from 1990 to 1995.

\subsection{The driving factors of agricultural landscape change}

\subsubsection{Policy}

The land-use policy appeared to have a strong impact on the land-use structure of the study area. The introduction of the "Household Responsibility System" in 1978 and the adoption of market-directed economy system in 1992 clearly increased the vigor of rural economy and caused a great alteration in the agricultural land-use structure. During 1958-1978, the rural land-use policy was of the commune system whereas the agricultural economy was dominated by grain production. Consequently, the main type of land use (i.e. grain production) was prone to excessive erosion. At the end of 1978, however, the commune system was replaced by the household responsibility system, and during this land reform stage the land 
(a)

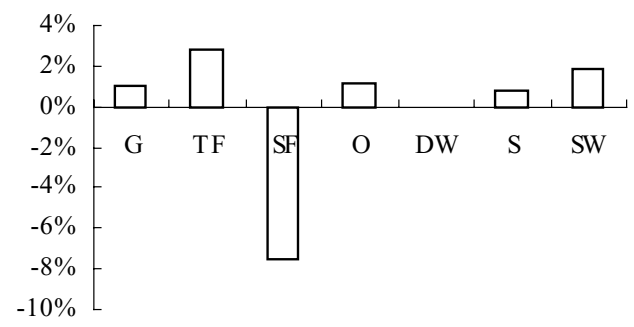

(c)

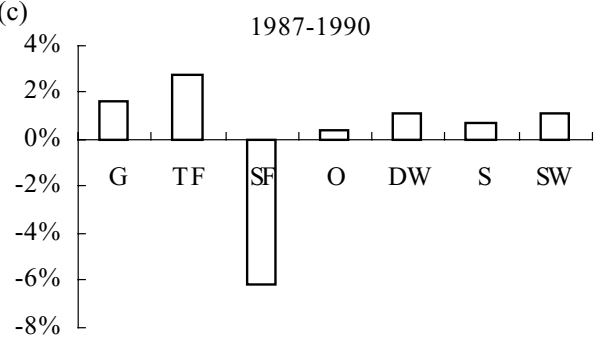

(b)

1978-1987

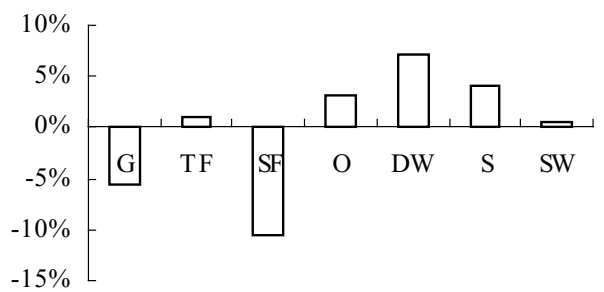

(d) $1990-1995$

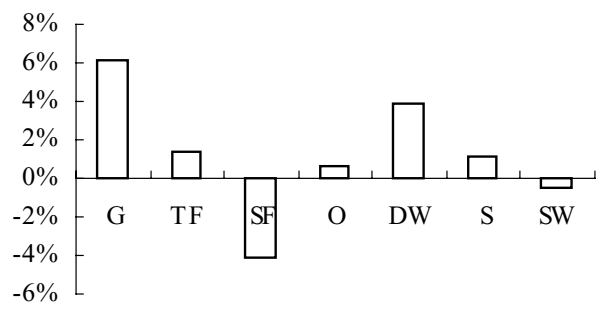

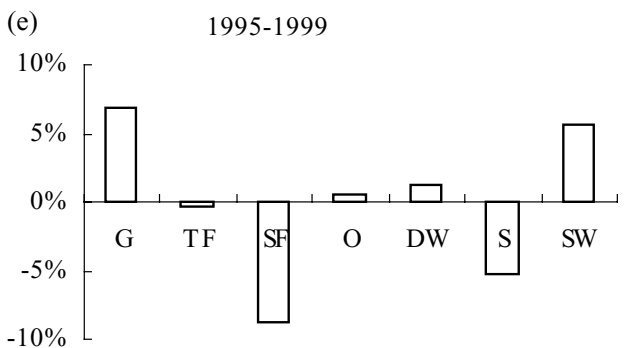

Fig. 3. The main land-use change in Zhifanggou catchment during the five periods for 1958-1978 (a), $1978-1987$ (b), $1987-1990$ (c), 1990-1995 (d) and 1995-1999 (e).

was redistributed to individual farmers. Since 1992, the market-directed economic system replaced the planned economic system, which resulted in a diversification of agricultural income sources. In 1999, woodland and grassland both reached about $40 \%$ of the total area, while farmland in strict sense only accounted for about $20 \%$ of the total area (Fig. 2).

In addition to the above, since the initiation of Chinese Family Planning (in 1978), "one couple one child", the population growth was effectively controlled and the conflict of population-land was alleviated to a great extent. Before the introduction of the Family Planning, the total population in Zhifanggou catchment increased from 221 persons in 1958 to 392 in 1978 (Fig. 4). The rapid population growth brought a heavy burden to agriculture in that arable land was

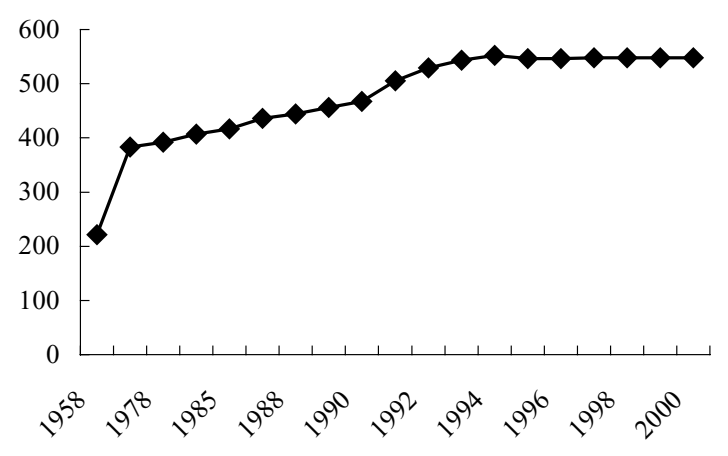

Fig. 4. The total population in Zhifanggou catchment from 1958 to 1999 . 
Table 2

The investment and control area of the integrated soil erosion control project carried out in Zhifanggou catchment from 1981 to 1999

\begin{tabular}{|c|c|c|c|c|c|c|c|c|}
\hline \multirow[t]{2}{*}{ Land use } & \multicolumn{2}{|c|}{ 1981-1985 } & \multicolumn{2}{|c|}{ 1986-1990 } & \multicolumn{2}{|c|}{ 1991-1995 } & \multicolumn{2}{|c|}{ 1996-1999 } \\
\hline & $\begin{array}{l}\text { Area } \\
\text { (ha) }\end{array}$ & $\begin{array}{l}\text { Investment } \\
\text { (Yuan) }\end{array}$ & $\begin{array}{l}\text { Area } \\
\text { (ha) }\end{array}$ & $\begin{array}{l}\text { Investment } \\
\text { (Yuan) }\end{array}$ & $\begin{array}{l}\text { Area } \\
\text { (ha) }\end{array}$ & $\begin{array}{l}\text { Investment } \\
\text { (Yuan) }\end{array}$ & $\begin{array}{l}\text { Area } \\
\text { (ha) }\end{array}$ & $\begin{array}{l}\text { Investment } \\
\text { (Yuan) }\end{array}$ \\
\hline Woodland & 68 & 13,708 & 44 & 11,616 & 33 & 10,780 & 33 & 2,000 \\
\hline Orchard & 10 & 3,000 & 19 & 9,860 & 6 & 2,520 & & 10,000 \\
\hline Grassland & 59 & 3,056 & 33 & 750 & 33 & 3,000 & 67 & 2,000 \\
\hline Terrace farmland & 3 & 15,000 & 26 & $22,500 / 4000^{\mathrm{a}}$ & 25 & $41,000 / 3958^{\mathrm{a}}$ & 7 & $40,000 / 1043^{\mathrm{a}}$ \\
\hline Check-dam farmland & & & 1 & 140,000 & & & & \\
\hline Total & 140 & 34,764 & 122 & 188,726 & 97 & 61,258 & 107 & 55,043 \\
\hline
\end{tabular}

${ }^{\mathrm{a}}$ The investment originated from farmer; source: Wang (2001).

maintained over $50 \%$ of the total area during 1958 and 1978. After Family Planning implementation, the population growth rate decreased from $1.11 \%$ in 1978 to $0.15 \%$ in 1999 , and the population fertility rate declined from 1.67 to $0.66 \%$ (ACSB, 1958-2000). By 1999, the total population reached 548 persons with 107 families and an average of 5.1 members per family in Zhifanggou catchment.

\subsubsection{Integrated soil erosion control project}

Because of the combined problems of soil erosion and economic underdevelopment in the study area, the government has paid much attention to soil and water conservation along with agricultural development. Since the implementation of an integrated soil erosion control project (started in 1981), a number of significant changes have occurred in the study area, including the building of terraces, the construction of check-dams, and reforestation (Table 2). In total 339,791 Yuan Renminbi (RMB) was invested and 466 ha erosion area was controlled in Zhifanggou catchment during 1981-1999. Consequently, the check-dam farmland and terrace farmland increased. These land-use types both provide a high and stable crop yield, and are successful in the preservation of soil moisture and fertility.

\subsubsection{Development in economy and advancement in technology}

From 1958 to 1999 , especially after 1992, China witnessed a rapid economic development. The economic development in the Zhifanggou catchment surrounding area, such as Xi'an and Yan'an, provided opportunity for off-farm work. This reduced the land-dependency of the farmer and altered the local economic income structure (Fig. 5). Another important driving factor of agricultural landscape change was the technological advancement, such as the introduction of chemical fertilizers and pesticides, the improvement of crop species, as well as the adoption of new tillage practices. All these technologies increased land productivity. As a result, the total grain yield obtaining from various types of farmland in Zhifanggou catchment increased, despite a decrease of total farmland area (Fig. 6).

\subsubsection{Farmer's attitude}

Another important force of land-use change was the change of local farmer's attitude. In the past, local agriculture was characterized by extensive cultivation and low productivity. Most parts of the land had been reclaimed as farmland (e.g. farmland in 1958 accounted for $58.2 \%$ of the total area), at the cost of

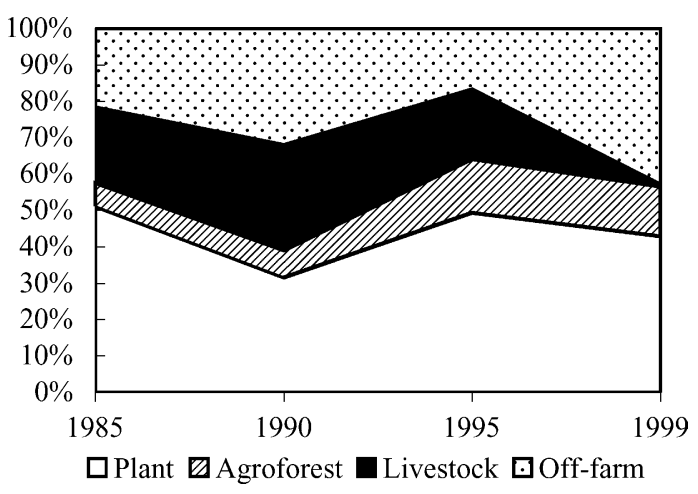

Fig. 5. The economic structure of Zhifanggou catchment during the period 1985-1999. 


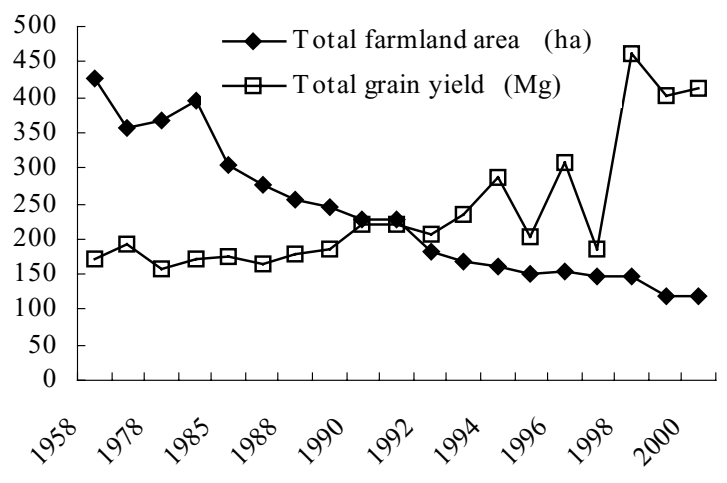

Fig. 6. The total farmland and grain yield of Zhifanggou catchment from 1958 to 2000.

woodland and grassland, which inevitably resulted in serious soil erosion. Consequently, land became less fertile and still more land was reclaimed to meet the need of the population growth. Since the implementation of integrated soil erosion control project (initiated in 1981), many conservation techniques have been introduced to Zhifanggou catchment, such as high yield crop cultivation, runoff collection and water saving irrigation. A new cultivation model, of mixed and intensive farming, replaced the traditional single-crop and extensive farming. For example, in order to increase economic income, more fruit trees have been planted. Orchard area increased from $4.5 \%$ in 1987 to $6.1 \%$ in 1999. Recently, some households in Zhifanggou village have started to plant cash crops, such as greenhouse vegetables, in the land near the highway to Ansai County.

\section{Discussion}

\subsection{Multi-temporal agricultural landscape change from 1958 to 1999}

In this study, multi-temporal land-use databases have been used to assess the changes in agricultural landscape using GIS within the past 41 years. Five periods can be distinguished, 1958-1978 (commune phase), 1978-1987 (the early stage of household responsibility system and the Sixth Five-year Plan), 1987-1990 (the Seventh Five-year Plan), 1990-1995 (the Eighth Five-year Plan and the early stage of market-oriented economy system), and 1995-1999 (the Ninth Five-year Plan). From 1958 to 1978, little farmland was converted to woodland or grassland. After 1978, farmland continued reducing and woodland kept increasing. Due to the implementation of a market-directed economic system, the agricultural landscape changed much more rapidly after 1992.

\subsection{Driving forces of agricultural landscape change}

At the end of 1999, Western Development policy was proposed in China in order to promote the economic development in Western China. At the same time, Western Ecological Environment Construction project was initiated, with "Grain to Green" and "Convert slope farmland into forest or pasture" as the main activity, aimed at "Rebuilding a graceful northwest with green mountains and clear water". The Loess Plateau, for its serious soil erosion, was regarded as the major soil and water conservation region. It is certain that this new policy must inevitably promote the agricultural development and influence the land use. The policy could still be the main driving force of land-use change in the Loess Plateau.

After the introduction of the household responsibility system, most lands were reallocated to individual farmers and most agricultural activities were undertaken in small groups. Therefore, it was difficult for single household to build terraces and check-dams due to lack of funds and labor without the support of the official organization, even if the local farmer was inclined to do so. For example, the terrace farmland decreased 6.6 ha from 1975 to 1997 in Danangou catchment of northern Loess Plateau (Chen et al., 2001). While in Zhifanggou catchment the terrace farmland increased 39.9 ha from 1978 to 1999 mainly due to the implementation of integrated soil erosion control project. So it is necessary for the soil and water conservation of the Loess Plateau to be invested and organized by the government.

The modification and conversion of land cover and land use are driven by the interaction in space and time between biophysical and human dimensions (Turner et al., 1993), whereas human factors determine where and to what extent land use is modified at a certain location (Verburg and Chen, 2000). This study analyzed the process of human-induced landscape change and the complex relationship between anthropogenic 
forces, such as policy reform, integrated soil erosion control project and the population growth, that induce the changes in land-use pattern. Although the current analysis does not include natural factors, such as slope degree and soil moisture, this study can provide a good framework to incorporate additional physical factors when they become available.

\subsection{Effects of landscape change}

The landscape changes produced greatly ecological benefits. The effective vegetation coverage (above $60 \%$ ) increased from $18.7 \%$ in 1985 to $43.7 \%$ in 1995 , and reached $57.4 \%$ by the end of 1999 . Consequently, the rate of soil erosion was decreased from $14,000 \mathrm{Mg} \mathrm{km}^{-2}$ per year before 1981 to $12,500 \mathrm{Mg} \mathrm{km}^{-2}$ per year by the end of 1985 . During the Seventh (1986-1990), the Eighth (1991-1995) and the Ninth Five-year Plan (1995-1999), the rate of soil erosion further decreased to 6355, 2593 and $2239 \mathrm{Mg} \mathrm{km}^{-2}$ per year (Liu et al., 2000), respectively.

Not only the ecological benefit was evident but also the economic benefit. A benign cycle was developed in the study area. The total grain yield increased from 170 to $401 \mathrm{Mg}$, although the total area of farmland had decreased from 426 to 120 ha from 1958 to 1999 . At the other hand, the annual income of the local farmer increased from 850 Yuan RBM per capita in 1985 to 1336 Yuan RBM per capita in 1995. Up to 1999, the local farmer's annual income had reached 2136 Yuan RBM per capita (Wang, 2000).

\section{Conclusions}

The study indicated that the land-use policy, the adaptation of the basic economic system, soil erosion conservation projects, as well as a population policy and the introduction of new technology were the main driving forces that jointly determined how farmers adapted land use and subsequently modified the landscape pattern.

The major agricultural landscape change took place during the period of 1958-1999, especially after 1978. Slope farmland shrank, and woodland and grassland expanded. Additionally, some high profit land-use types, such as terrace farmland and check-dam farm- land increased in area. From the viewpoint of soil erosion control and the farmer's living improvement, the present land-use structure is better and more acceptable than the former.

\section{Acknowledgements}

This project was supported by the National Natural Science Foundation of China for the Grand Research Plan (Contract No. 90102018). It is also supported by bilateral collaboration programme Flanders-China, "Farming system analysis and land use evaluation towards sustainable land use in the loess hilly area of China". The authors would like to thank Prof. Junliang Tian for his help on data collection and Mr. Rongjin Yang for the cooperation during household questionnaires. At the same time, the authors wish to acknowledge the two anonymous reviewers for constructive comments, which helped us in improving the contents and presentation of the manuscript.

\section{References}

ACSB (Ansai County Statistics Bureau) (Ed.), 1958-2000. Ansai County National Economy Statistic Yearbook. Ansai County Press, Ansai (in Chinese).

Burel, F., Baudry, J., Lefeuvre, J.C., 1993. Landscape structure and the control of water runoff. In: Bunce, R.G.H., Ryszkowski, L., Paoletti, M.G. (Eds.), Landscape Ecology and Agroecosystems. Lewis, Boca Raton, FL, pp. 41-47.

Bürgi, M., Turner, M.G., 2002. Factors and processes shaping land cover and land cover changes along the Wisconsin river. Ecosystems 5, 184-201.

Chen, L.D., Wang, J., Fu, B.J., Qiu, Y., 2001. Land use change in a small catchment of northern Loess Plateau China. Agric. Ecosyst. Environ. 86 (2), 163-172.

COSTLOP-CAS (Comprehensive Survey Term on Loess Plateau of Chinese Academy of Sciences), 1991. The Natural Environmental Characteristics and Environment. China Science and Technology Press, Beijing (in Chinese).

FAO-UNESCO, 1974. Soil Map of the World (1:5,000,000). Food and Agricultural Organisation of the United Nations, UNECO, Paris.

Forman, R.T., Gordron, M., 1986. Landscape Ecology. Wiley, New York, p. 620.

Fu, B., Gulinck, H., 1994. Land evaluation in the Loess Plateau of sever erosion: the Loess Plateau of China. Land Degrad. Rehabil. 5, 33-40.

Fu, B., Gulinck, H., Masum, M.Z., 1994. Loess erosion in relation to land-use changes in the ganspoel catchment, Central Belgium. Land Degrad. Rehabil. 5, 261-270. 
Fu, B.J., 1989. Soil erosion and its control in the Loess Plateau of China. Soil Use Manage. 5 (2), 76-82.

Fu, B.J., Chen, L.D., 2000. Agricultural landscape spatial pattern analysis in the semi-arid hill area of the Loess Plateau, China. J. Arid Environ. 44 (3), 291-303.

Imberson, J., 1999. Pattern and development of land-use change in the Kenyan highlands since the 1950s. Agric. Ecosyst. Environ. 76, 67-73.

Jiang, D. (Ed.), 1997. Soil Erosion and Control Models in the Loess Plateau. China Hydroelectricity Press, Beijing (in Chinese).

Kammerbauer, J., Ardon, C., 1999. Land use dynamics and landscape change pattern in a typical watershed in the hillside region of central Honduras. Agric. Ecosyst. Environ. 75, 93100.

Krausmann, F., Haberl, H., Schulz, N.B., Erb, K.H., Darge, E., Gaube, V., 2003. Land-use change and socio-economic metabolism in Austria. Part I. Driving forces of land-use change: 1950-1995. Land Use Policy 20, 1-20.

Liu, W.Z., Liang, Y.M., Hou, X.L., Liu, G.B., 2000. To change steep cropland into grassland and woodland and strengthen ecoagricultural construction. Sci. Technol. Rev. 7, 51-53 (in Chinese).

Meyer, W.B., Turner II, B.L., 1991. Changes in Land Use and Land Cover: A Global Perspective. Cambridge University Press, Cambridge.

Paquette, S., Domon, G., 1997. The transformation of the agroforestry landscape in the nineteenth century: a case study in southern Quebec (Canada). Landscape Urban Plan. 37, 197209.

Peterjohn, W.T., Correll, D.L., 1984. Nutrient dynamics in an agricultural watershed: observations on the role of a riparian forest. Ecology 65, 1466-1475.
Poudevigne, I., Van Rooij, S., Morin, P., Morin, P., Alard, D., 1997. Dynamics of rural landscape and their main driving factors: a case study in the Seine Valley, Normandy, France. Landscape Urban Plan. 38, 93-103.

Rao, K.S., Pant, R., 2001. Land use dynamics and landscape change pattern in a typical micro watershed in the mid elevation zone of central Himalaya, India. Agric. Ecosyst. Environ. 86, 113-123.

Reenberg, A., 2001. Agricultural land use pattern dynamics in the Sudan-Sahel-towards an event-driven framework. Land Use Policy 18, 309-319.

Seilbernagel, J., Martin, S.R., Gale, M.R., Chen, J., 1997. Prehistoric, historic, and present settlement patterns related to ecological hierarchy in the Eastern Upper Peninsula of Michigan, USA. Landscape Ecol. 12, 223-240.

Turner II, B.L., Moss, R.H., Skole, D.L., 1993. Relating land use and global land-cover change: a proposal for on IGBP-HDP Core Prodect. IGBP Report 24, Stockholm, Sweden, HDP Report 5.

Verburg, P.H., Chen, Y.Q., 2000. Multiscale characterization of land-use patterns in China. Ecosystems 3, 369-385.

Wang, J.J., 2000. Study on the ecological and economic system development in Zhifanggou Valley. World Sci.-Tech. R\&D 22 (5), 85-88 (in Chinese).

Wang, J.J., 2001. Analysis on the construction and input of ecological economy system of agriculture in Zhifanggou Valley. World Sci.-Tech. R\&D 23 (3), 6-58 (in Chinese).

Wilson, W.L., Abernethy, V.J., Murphy, K.J., Adam, A., McCrachen, D.I., Downie, I.S., Foster, G.N., Furness, R.W., Waterhouse, A., Ribera, I., 2003. Prediction of plant diversity response to land-use change on Scottish agricultural land. Agric. Ecosyst. Environ. 94, 249-263. 